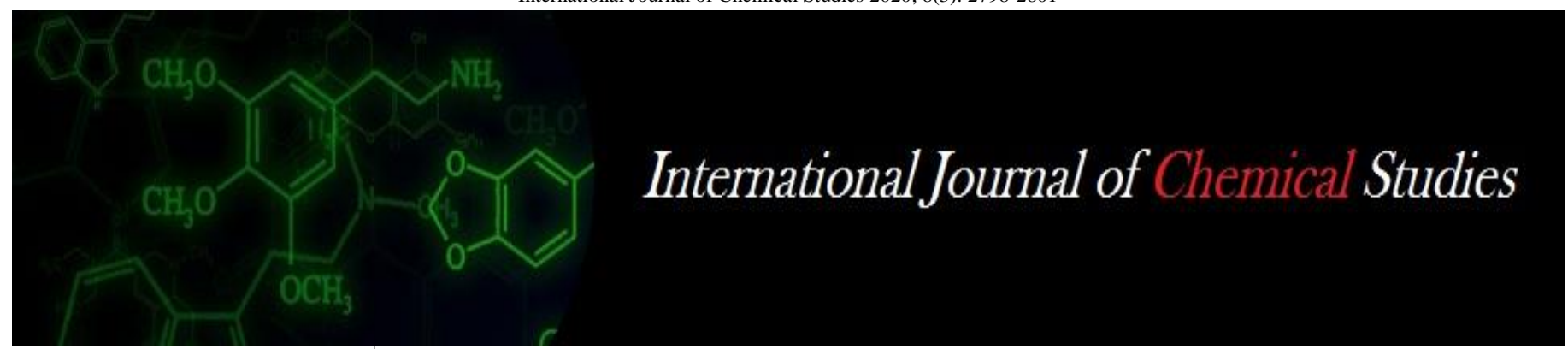

P-ISSN: 2349-8528

E-ISSN: 2321-4902

www.chemijournal.com

IJCS 2020; 8(3): 2798-2801

(C) 2020 IJCS

Received: 03-03-2020

Accepted: 06-04-2020

\section{Dr. R Jeyasrinivas}

Department of Agronomy, TNAU, Coimbatore, Tamil Nadu, India

\section{Dr. A Balakrishnan}

Department of Agronomy, TNAU, Coimbatore, Tamil Nadu, India

\section{Dr. S Juliet Hepziba}

Department of Agronomy,

TNAU, Coimbatore, Tamil

Nadu, India

Dr. P Murali Arthanari Department of Agronomy, TNAU, Coimbatore, Tamil Nadu, India
Corresponding Author: Dr. R Jeyasrinivas

Department of Agronomy, TNAU, Coimbatore, Tamil Nadu, India

\section{Studies on pre and post emergence herbicidal weed management in hybrid maize $\mathrm{COH}(\mathrm{M}) 6$ (Zea mays)}

\author{
Dr. R Jeyasrinivas, Dr. A Balakrishnan, Dr. S Juliet Hepziba and Dr. P \\ Murali Arthanari
}

DOI: https://doi.org/10.22271/chemi.2020.v8.i3ao.9637

\begin{abstract}
In general, Maize is one of the most important cereal crops in the world's agricultural economy both as food for human being and feed for animals. Among the cereals, maize is the important cereal crop next to rice and wheat. Weeds are generally vigorous growers and their nutrient requirements are often greater than that of crop plants. Major area of maize in India is during Kharif season in which weed is one of the important yield limiting factor and significantly reduces the yield. Hence this condition the research sub project is proposed to evaluate suitable recommendations and combination of pre and early post emergence application herbicide management for hybrid maize $\mathrm{CO}(\mathrm{MH})$ 6. A field experiment was conducted during 2016 (Aug -Sep), 2017 (Aug -Sep),\& 2018 (Jan- Feb) at Agricultural Research Station, Vaigai Dam The treatment consisted that alachlor $1.25 \mathrm{~kg} \mathrm{ha}^{-1}$ with addition of one hand weeding on 30 DAS, alachlor $1.0 \mathrm{~kg} \mathrm{ha}^{-1}$ coupled with tembotrione $120 \mathrm{~g} \mathrm{ha}^{-1}$ on $30 \mathrm{DAS}$, atrazine $0.5 \mathrm{~kg} \mathrm{ha}^{-1}$ with addition of one hand weeding on 30 DAS, atrazine $0.5 \mathrm{~kg} \mathrm{ha}^{-1}$ coupled with early post emergence herbicide of Tembotrione $120 \mathrm{~g} \mathrm{ha}^{-1}$, Tembotrione $120 \mathrm{~g} \mathrm{ha}^{-1}$ alone, hand weeding twice on 20 and 40 DAS and control (Unweeded control). From the experiments it can be concluded that the pre-emergence application of Atrazine $0.5 \mathrm{~kg} \mathrm{ha}^{-1}$ with addition with addition of early post emergence herbicide of Tembotrione $120 \mathrm{~g} \mathrm{ha}^{-1}$ has recorded higher grain and stover yield.
\end{abstract}

Keywords: Maize, atrazine, alachlor, tembotrione, weed management

\section{Introduction}

Maize (Zea mays L.) is a miracle crop is grown over a wide range of climatic conditions in semi-arid and sub tropics on climatic conditions in semi-arid and sub tropics on Indian continent. It ranks third most important food grain crop after rice and wheat in India providing food, feed, fodder and also serves as a source of basic raw materials for number of industrial products for food (25\%) animal feed (12\%) (Dass et al., 2008) ${ }^{[2]}$. About $80 \%$ of maize growing area in India fall under rainfed sub-tropical climate. Weeds are generally vigorous growers and their nutrient requirements are often greater than that of crop plants. Major area of maize in India is during kharif season in which weeds is one of the important yields limiting factor and significantly reduces the yield. The absence of appropriate crop management practices, weed damage to the maize crop may be as high as 50-75\%. However the critical period for crop weed completion are first six weeks after planting of crop because of initial slow growth and wider row spacing of maize coupled with congenial weather condition allow luxuriant growth which may reduce yield by $28-100 \%$. Recurring of weeds is another limiting factor in the crop production as they the crop yield and detoriate the quality of produce and hence reduction the market value of turn out (Arif et al.,2006) ${ }^{[1]}$. In addition, weeds reduce the soil fertility, available moisture and nutrients, competed for space and light with crop plants, which result in yield reduction (Khan et al.,2004) ${ }^{[6]}$. Amongst various production factors, weed management plays major role in increasing productivity of maize. Unchecked weed growth in crop may results in grain yield losses to extent of 100\% (Sharma 2005). Even though herbicides are effective in controlling weeds, application of single pre emergence (PE)and Post emergence (PoE) herbicides does not provide satisfactory weed control for particular period (Malviya and Singh 2007) ${ }^{[8]}$. 
The experiment was laid with the view to find out the pre and post herbicidal and their combination on productivity of maize.

\section{Materials and Methods}

A field experiment was conducted during 2016 (Aug -Sep), 2017 (Aug -Sep), \& 2018 (Jan- Feb) at Agricultural Research Station, Vaigai Dam at $\mathrm{N}$ latitude and Longitude of $\mathrm{E}$ an altitude of $\mathrm{M}$ above mean sea level. The soil of experimental site was clayey loam in texture, slightly alkaline in reaction, low in organic carbon and nitrogen, Medium in available in phosphorous and high in available in potassium. The experiment was laid out in Randomized block design with three replications involving seven treatments. Before sowing field was thoroughly ploughed and leveled with fertilizer dose of 250:75:75 kg N,P and $\mathrm{K} \mathrm{ha}^{-1}$. Half dose of $\mathrm{N}$ and full dose of $\mathrm{P}$ and $\mathrm{K}$ were applied as basal. Remaining $50 \%$ of $\mathrm{N}$ were applied on 25 DAS and 45 DAS through top dressing of urea. The herbicides as per the treatments were applied by battery operated sprayer using 500 liter of water/ha. Weed density was recorded at 20 DAS,40 DAS\&60DAS by using a quadrate of $100 \mathrm{~cm} \mathrm{X} 100 \mathrm{~cm}\left(1 \mathrm{~m}^{2}\right)$ size from the centre of the plot. The entire weeds inside the quadrate were uprooted and cut close to the transition of root and shoot in each plot and collected for dry matter accumulation (biomass). The samples were first dried in sun and then kept in oven $72+2$. C. The dried samples were weighed and expressed as biomass $\left(\mathrm{g} \mathrm{m}^{-}\right.$ ${ }^{2}$ ). The cost of cultivation, gross returns, net returns and benefit cost ration for each treatment were calculated by taking into consideration of total cost incurred and returns obtained. Square root transformation was done for 0.5 weed control efficiency was calculated by Gill and Vijayakumar $(1969)^{[4]}$.

\section{Results and Discussion Weed flora}

The experimental field was infested with grasses, sedges and broad leaved weeds were observed. The major grassy weeds like Dinebra retroflexa, Echinoclova colonam Dactyloctenium aegiptium, Panicum flavidum and Brachiaria reptans in grasses, the Cyprus rotundus was the only sedge and Broadleaved weeds are Corchorus olitorius, Digera arvensis, cleome viscosa, Phyllanthus niruri, Euphorbia hirta, Trianthema portulacasturm, Eclipta alba, Pterocarpus jamaisensis, Parthenium histerophorus, Euphorbia hirta,, Bohavia diffusa and Phyllanthus madras petensis were the major broad leaved weeds in the experimental trial.

\section{Effect on weeds}

\section{Effect on weed population}

The pre emergence of atrazine $0.5 \mathrm{~kg} \mathrm{ha}^{-1}$ with the addition of post emergence of herbicide Tembotrione $120 \mathrm{~g} \mathrm{ha}^{-1}$ was recorded significantly lower weed population at 20,40 and 60 DAS during three years (Deshmukh et al., 2009) ${ }^{[3]}$. This was closely followed by alachlor $1.0 \mathrm{~kg} \mathrm{ha}^{-1}$ followed by post emergence application of Tembotrione $120 \mathrm{ha}^{-1}$. The post emergence application of Tembotrione $120 \mathrm{~g} \mathrm{ha}^{-1}$ did not significantly influence on weed population. Unweeded control was recorded higher weed population than other treatments at 20,40,60 DAS. However, hand weeding twice on 20 and 40 DAS recorded lower weed population on 40 and 60 Das. It was closely on par with above herbicide treatments (Table 1).

\section{Effect on weed biomass}

The weed biomass significantly low with atrazine $0.5 \mathrm{~kg}$ followed by post emergence application of Tembotrione $120 \mathrm{~g}$ $\mathrm{ha}^{-1}\left(1.57 \mathrm{~g} \mathrm{~m}^{2}\right)$ which was on par with pre emergence application of alachlor $1.0 \mathrm{~kg}$ with post emergence application of Tembotrione $120 \mathrm{~g} \mathrm{ha}^{-1}\left(1.89 \mathrm{~g} \mathrm{~m}^{2}\right)$, Atrazine followed by hand weeding $\left(2.41 \mathrm{~g} \mathrm{~m}^{2}\right)$. These results are in accordance with Triveni et al., (2017) ${ }^{[10]}$. During the three years, weed biomass was significantly high in weedy check.

\section{Effect on weed control efficiency}

Among the pre and post herbicidal treatments, higher weed control efficiency (WCE) at 20 DAS was observed with atrazine $0.5 \mathrm{~g} \mathrm{ha}^{-1}$ followed by Tembotrione $120 \mathrm{~g} \mathrm{ha}^{-1}$ $(83.3 \%, 82.0 \%$ and $80.6 \%)$ (Table 1$)$ respectively, which was on par with alachlor $1.0 \mathrm{~kg}$ followed by Tembotrione $120 \mathrm{~g} / \mathrm{ha}$ at 20, 40 and 60 DAS. (Table 1). Joseph et al., (2008) ${ }^{\text {[5] }}$ reported that tank mix application of Tembotrione and atrazine as early post emergence in maize resultant in excellent control of grassy weeds. Hand weeding twice recorded higher weed control efficiency $(78.8 \%, 70.9 \%)$ in 40 and $60 \mathrm{DAS}$. Those results were conformity with the findings reported by Kumar et al., (2013) ${ }^{[7]}$.

\section{Effect of Growth and yield}

Among the various weed control treatments, the plant height was maximum reached under the atrazine followed by Tembotrione which was on par with alachlor followed by Tembotrione atrazine followed by one hand weeding and hand weeding twice. The yield attributes viz., cob length, number of seeds/cob, were significantly higher in atrazine followed by Tembotrione. The number of cobs/plant was no significantly differentiated in herbicide treatments. The yield parameters were higher in atrazine followed by Tembotrione which was at par with alachlor followed by Tembotrione. The post emergence application of Tembotrione did not significantly influence of yield parameters.

\section{Grain and Stover yield}

Grain and stover yield were significantly higher in herbicidal treatments. During three years revealed that grain and stover yield was higher in atrazine followed by Tembotrione (5918 and $9604 \mathrm{~kg}$ ) respectively which was closely on par with alachlor followed by Tembotrione $(5711 \& 9356 \mathrm{~kg})$ and hand weeding twice (5742 \&9143 kg/ha). The Tembotrione alone did not significantly influence on grain and stover yield. Unweeded control recorded lowest grain and stover yield (Table 2). The above results was conformity with the findings reported by Swetha (2015) ${ }^{[9]}$.

\section{Economics of cultivation}

Preference of any herbicides by the farmers mainly depends on the weed control efficiency and economics. Generally, hand weeding is more expensive than the chemical weed control. Among the weed control treatments, net returns and benefit cost ratio were found to be higher in the treatment of atrazine followed by Tembotrione during the three years. Lowest net return and benefit cost ratio (Rs. 7518 \&1.20) was recorded in Unweeded control mainly because of declined yield due to heavy weed infestation (Table 3).

It was concluded that pre emergence application of atrazine $0.5 \mathrm{~kg} / \mathrm{ha}$ with addition of early post emergence application of Tembotrione $120 \mathrm{~g} \mathrm{ha}^{-1}$ was found effective in improving weed control, yield and economics. Hence it is recommended for hybrid maize crop. 
Table 1: Effect of different pre and post weed management methods on weed density, weed biomass and weed control efficiency at different days interval of maize hybrid $\mathrm{COH}(\mathrm{M}) 6$ (Pooled mean analysis)

\begin{tabular}{|c|c|c|c|c|c|c|c|c|c|c|}
\hline \multirow{2}{*}{$\begin{array}{l}\text { S. } \\
\text { No }\end{array}$} & \multirow[t]{2}{*}{ Treatment } & \multicolumn{3}{|c|}{$\begin{array}{l}\text { Total weed population } \\
\left(\mathrm{No}^{-2}\right)\end{array}$} & \multicolumn{3}{|c|}{$\begin{array}{c}\text { Total weed dry matter } \\
\qquad\left(\mathrm{g} \mathrm{m}^{-2}\right)\end{array}$} & \multicolumn{3}{|c|}{$\begin{array}{l}\text { Weed control } \\
\text { efficiency }(\%)\end{array}$} \\
\hline & & 20 & 40 & 60 & 20 & 40 & 60 & 20 & 40 & 60 \\
\hline 1. & $\begin{array}{l}\mathrm{T}_{1} \text { - Pre emergence application of alachlor } 1.5 \mathrm{~kg} \mathrm{ha}^{-1}+\mathrm{HW} \text { on } \\
\text { 30 DAS. }\end{array}$ & $\begin{array}{c}5.15 \\
(20.8)\end{array}$ & $\begin{array}{c}4.65 \\
(17.3)\end{array}$ & $\begin{array}{c}6.39 \\
(37.9) \\
\end{array}$ & $\begin{array}{c}2.63 \\
(5.54) \\
\end{array}$ & $\begin{array}{c}3.21 \\
(5.92)\end{array}$ & \begin{tabular}{|c|}
4.99 \\
$(22.4)$
\end{tabular} & 70.2 & 78.3 & 66.5 \\
\hline 2. & $\begin{array}{c}\mathrm{T}_{2} \text { - Pre emergence application of alachlor } 1.0 \mathrm{~kg} \mathrm{ha}^{-1}+\text { Post } \\
\text { emergence herbicide Tembotrione } 120 \mathrm{~g} \mathrm{ha}^{-1} \text { at } \\
\text { 20 DAS. }\end{array}$ & $\begin{array}{c}4.31 \\
(17.4)\end{array}$ & $\begin{array}{c}3.92 \\
(11.9)\end{array}$ & $\begin{array}{l}5.45 \\
(29.3)\end{array}$ & $\begin{array}{c}1.89 \\
(2.19)\end{array}$ & $\begin{array}{c}2.94 \\
(3.55)\end{array}$ & $\begin{array}{c}4.27 \\
(15.3)\end{array}$ & 79.0 & 81.3 & 75.4 \\
\hline 3. & $\begin{array}{l}\mathrm{T}_{3} \text { - Pre emergence application of Atrazine } 0.5 \mathrm{~kg} \mathrm{ha}^{-1}+\mathrm{HW} \text { on } \\
\text { 30 DAS. }\end{array}$ & $\begin{array}{c}3.98 \\
(13.4)\end{array}$ & & $\begin{array}{c}5.56 \\
(26.4)\end{array}$ & $\begin{array}{c}2.41 \\
(4.42)\end{array}$ & $\begin{array}{c}3.46 \\
(8.01)\end{array}$ & $\begin{array}{c}4.24 \\
(14.03)\end{array}$ & 73.3 & 80.7 & 72.8 \\
\hline 4. & $\begin{array}{l}\text { T4- Pre emergence application of Atrazine } 0.5 \mathrm{~kg} \mathrm{ha}^{-1}+\text { Post } \\
\text { emergence herbicide Tembotrione } 120 \mathrm{~g} \mathrm{ha}^{-1} \text { at } \\
\text { 20 DAS. }\end{array}$ & $\begin{array}{l}3.07 \\
(7.83)\end{array}$ & $\begin{array}{c}3.37 \\
(8.63)\end{array}$ & $\begin{array}{c}4.18 \\
(16.5)\end{array}$ & $\begin{array}{c}1.57 \\
(1.28)\end{array}$ & $\begin{array}{l}2.59 \\
(2.64)\end{array}$ & $\begin{array}{l}3.41 \\
(8.9)\end{array}$ & 83.3 & 82.0 & 80.6 \\
\hline 5. & $\begin{array}{l}\mathrm{T}_{5} \text { - Post emergence herbicide Tembotrione } 120 \mathrm{~g} \mathrm{ha}^{-1} \text { at } 20 \\
\text { DAS. }\end{array}$ & $\begin{array}{l}10.03 \\
(96.3) \\
\end{array}$ & $\begin{array}{c}4.76 \\
(18.6) \\
\end{array}$ & $\begin{array}{c}7.44 \\
(54.4) \\
\end{array}$ & $\begin{array}{c}5.55 \\
(26.14) \\
\end{array}$ & $\begin{array}{c}3.73 \\
(7.08) \\
\end{array}$ & \begin{tabular}{|c|}
5.75 \\
$(28.9)$ \\
\end{tabular} & 34.2 & 77.6 & 62.4 \\
\hline 6. & $\mathrm{~T}_{6}$ - Hand weeding twice at $20^{\text {th }}$ and $40^{\text {th }}$ DAS. & $\begin{array}{c}13.2 \\
(103.4)\end{array}$ & $\begin{array}{c}4.58 \\
(16.9)\end{array}$ & $\begin{array}{c}5.93 \\
(31.2)\end{array}$ & $\begin{array}{c}5.34 \\
(25.9)\end{array}$ & $\begin{array}{c}3.18 \\
(5.42)\end{array}$ & $\begin{array}{c}4.69 \\
(18.6)\end{array}$ & 44.9 & 78.8 & 70.9 \\
\hline 7. & $\mathrm{~T}_{7-}$ Unweeded control. & $\begin{array}{c}50.14 \\
(163.2)\end{array}$ & $\begin{array}{c}16.8 \\
(282.1)\end{array}$ & $\begin{array}{c}20.03 \\
(382.7)\end{array}$ & $\begin{array}{c}8.20 \\
(59.41)\end{array}$ & $\begin{array}{c}12.25 \\
(143.9)\end{array}$ & $\begin{array}{c}14.51 \\
(202.3)\end{array}$ & 6.8 & 0.0 & 0.0 \\
\hline & S.E.d & 0.674 & 0.570 & 0.782 & 0.463 & 0.398 & 0.358 & & & \\
\hline & $\mathrm{CD}(\mathrm{P}=0.05)$ & 1.47 & 1.243 & 1.243 & 1.010 & 0.866 & \begin{tabular}{|l|}
0.758 \\
\end{tabular} & & & \\
\hline
\end{tabular}

Table 2: Effect of different pre and post weed management methods on growth and yield attributes and yield of maize hybrid COH (M) 6 (Pooled mean analysis)

\begin{tabular}{|c|c|c|c|c|c|c|c|}
\hline $\begin{array}{l}\text { S. } \\
\text { No }\end{array}$ & Treatment & $\begin{array}{c}\text { Plant } \\
\text { height }(\mathbf{c m})\end{array}$ & $\begin{array}{c}\text { No of } \\
\text { seeds/Cob }\end{array}$ & $\begin{array}{c}\text { No. of } \\
\text { cobs/Plant }\end{array}$ & $\begin{array}{c}\text { Cob length } \\
\text { (cm) }\end{array}$ & $\begin{array}{c}\text { Grain } \\
\text { Yield } \\
\left(\mathrm{kgha}^{-1}\right)\end{array}$ & $\begin{array}{c}\text { Stover yield } \\
\left(\text { kgha }^{-1}\right)\end{array}$ \\
\hline 1. & $\begin{array}{l}\mathrm{T}_{1} \text { - Pre emergence application of alachlor } 1.5 \mathrm{~kg} \mathrm{ha}^{-1}+\mathrm{HW} \text { on } \\
\text { 30 DAS. }\end{array}$ & 223.07 & 389.9 & 1.03 & 18.4 & 5439 & 8854 \\
\hline 2. & $\begin{array}{c}\mathrm{T}_{2} \text { - Pre emergence application of alachlor } 1.0 \mathrm{~kg} \mathrm{ha}^{-1}+\text { Post } \\
\text { emergence herbicide Tembotrione } 120 \mathrm{~g} \mathrm{ha}^{-1} \text { at } 20 \text { DAS. }\end{array}$ & 236.7 & 397.7 & 1.03 & 19.5 & 5711 & 9356 \\
\hline 3. & $\begin{array}{l}\text { T3- Pre emergence application of Atrazine } 0.5 \mathrm{~kg} \mathrm{ha}^{-1}+\mathrm{HW} \text { on } \\
\text { 30 DAS. }\end{array}$ & 228.6 & 397.8 & 1.13 & 18.9 & 5655 & 9365 \\
\hline 4. & $\begin{array}{c}\mathrm{T}_{4} \text { - Pre emergence application of Atrazine } 0.5 \mathrm{~kg} \mathrm{ha}^{-1}+\text { Post } \\
\text { emergence herbicide Tembotrione } 120 \mathrm{~g} \mathrm{ha}^{-1} \text { at } 20 \mathrm{DAS} \text {. }\end{array}$ & 237.7 & 400.8 & 1.11 & 20.1 & 5918 & 9604 \\
\hline 5. & $\begin{array}{l}\text { T5- Post emergence herbicide Tembotrione } 120 \mathrm{~g} \mathrm{ha}^{-1} \text { at } \\
\text { 20 DAS. }\end{array}$ & 213.4 & 378.2 & 1.03 & 17.3 & 4842 & 8486 \\
\hline 6. & $\mathrm{~T}_{6-}$ Hand weeding twice at $20^{\text {th }}$ and $40^{\text {th }}$ DAS. & 228.9 & 394.9 & 1.14 & 19.1 & 5742 & 9143 \\
\hline \multirow[t]{3}{*}{7.} & T7- Unweeded control. & 192.6 & 267.2 & 1.00 & 14.8 & 2437 & 3853 \\
\hline & S.E.d & 6.2 & 26.7 & 0.053 & 0.79 & 202.1 & 414.5 \\
\hline & $\mathrm{CD}(\mathrm{P}=0.05)$ & 13.6 & 58.2 & NS & 1.71 & 440.5 & 903.3 \\
\hline
\end{tabular}

Table 3: Effect of different weed management methods on economic evaluation of maize hybrid 6 COH (M) 6 (Pooled mean analysis)

\begin{tabular}{|c|c|c|c|c|c|}
\hline $\begin{array}{l}\text { S. } \\
\text { No. }\end{array}$ & Treatment & $\begin{array}{c}\text { Cost of } \\
\text { cultivation } \\
\left(\text { Rs ha }^{-1}\right)\end{array}$ & $\begin{array}{c}\text { Gross } \\
\text { return } \\
\left(\text { Rs ha }^{-1}\right)\end{array}$ & \begin{tabular}{|c|} 
Net \\
return \\
$\left(\right.$ Rs ha $\left.^{-1}\right)$
\end{tabular} & $\begin{array}{l}\text { B:C } \\
\text { ratio }\end{array}$ \\
\hline 1. & $\mathrm{~T}_{1}$ - Pre emergence application of alachlor $1.5 \mathrm{~kg} \mathrm{ha}^{-1}+\mathrm{HW}$ on $30 \mathrm{DAS}$. & 53760 & 102329 & 53760 & 1.90 \\
\hline 2. & $\begin{array}{l}\mathrm{T}_{2} \text { - Pre emergence application of alachlor } 1.0 \mathrm{~kg} \mathrm{ha}^{-1}+\text { Post emergence herbicide Tembotrione } 120 \mathrm{~g} \\
\mathrm{ha}^{-1} \text { at } 20 \text { DAS. }\end{array}$ & 49800 & 107476 & 57676 & 2.16 \\
\hline 3. & $\begin{array}{l}\text { T3- Pre emergence application of Atrazine } 0.5 \mathrm{~kg} \mathrm{ha}^{-1}+\mathrm{HW} \text { on } \\
\text { 30 DAS. }\end{array}$ & 52800 & 106473 & 53673 & 2.02 \\
\hline 4. & $\begin{array}{l}\mathrm{T}_{4} \text { - Pre emergence application of Atrazine } 0.5 \mathrm{~kg} \mathrm{ha}^{-1}+\text { Post emergence herbicide Tembotrione } 120 \mathrm{~g} \\
\text { ha }^{-1} \text { at } 20 \text { DAS. }\end{array}$ & 50360 & 111326 & 60966 & 2.21 \\
\hline 5. & T5- Post emergence herbicide Tembotrione $120 \mathrm{~g} \mathrm{ha}^{-1}$ at $20 \mathrm{DAS}$. & & & 41100 & 1.82 \\
\hline 6. & $\mathrm{~T}_{6}-$ Hand weeding twice at $20^{\text {th }}$ and $40^{\text {th }}$ DAS. & & & & 1.96 \\
\hline 7. & $\mathrm{~T}_{7}$ - Unweeded control. & 38275 & 45793 & 7518 & 1.20 \\
\hline
\end{tabular}

\section{References}

1. Arif M, Khan MA, Akbar H, Sajjad, Ali. Prospects of wheat as a dual purpose crop and its impact on weeds. Pakistan Journal of weed science Research. 2006; 12(12):13-17.

2. Dass S, Jat ML, Singh KP, Rai HK. Agro economic analysis of maize based cropping system in India. Indian Journal of Fertilizers. 2008; 4:49-62.
3. Deshmukh LS, Adavas J, Jathure RS, Raskar SK. Effect of nutrient and weed management on weed growth and productivity of kharif maize under rainfed condition Karnataka Journal of Agricultural Sciences. 2009; 22(4):889-891.

4. Gill GS, Vijayakumar. Weed index A new method for reporting weed control trials Indian Journal of Agronomy. 1969; 16:96-98. 
5. Joseph D, Bollmam M, Boerboom Roger L, Becker and Friz. Efficiency of HPPD-Inhibiting herbicides in sweet corn. Weed Technology. 2008; 22:666-674.

6. Khan I, Hasssan G, Khan MI, Khan IA. Efficiency of some new herbicidal molecules on grassy and broad leaf weeds in wheat II. Pakistan Journal of Weed science Research. 2004; 10(1-2):33-38.

7. Kumar B, Kumar R, Kalyani S, Haque M. Integrated weed management studies on weed flora and yield in Kharif maize Trends in Biosciences. 2013; 6(2):161-164.

8. Malviya A, Singh B. Weed dynamics, productivity and economics of maize (Zea mays) as affected by integrated weed management under rainfed conditions. Indian Journal of Agronomy. 2007; 52(4):321-324.

9. Swetha K. Weed Management with new generation herbicides in Kharif maize (Zea maize L.) M.Sc. thesis, Department of Agronomy, Professor Jeyashankar Telengana state Agricultural University, Rajendra Nagar Hyderabad, 2015, 500-030.

10. Triveni U, Sandhyarani Y, Patro TSSK, Bharathalaksmi M. Effect of different pre and post emergence herbicides on weed control productivity and economics of maize, 2017. 